\title{
Dinamika Relasi Gender, Fakultas dan Lembaga di Lingkungan Universitas Malikussaleh: Catatan Awal
}

\author{
Jamaluddin, Apridar, Nanda Amali, Al Chaidar \\ Universitas Malikussaleh, Aceh, Indonesia
}

\section{Abstract}

This article argues that in the context of Malikussaleh University, the position of women is still often confronted with the position of men. The position of women is always associated with the domestic environment related to matters of family and household. While the position of men is often associated with the public environment related to matters outside the home. In a social structure, the position of such women is difficult to balance the position of men. Women who want to take part in the public sphere, it is still difficult to escape from their responsibilities in the domestic sphere. Women in this case are powerless to avoid the double burden because their duties as caretakers are a general cultural perception. Cultural control seems to be more stringent to women than men

Keywords

gender, Uhimal; man; woman, student

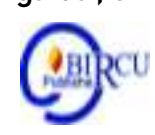

\section{Pendahuluan}

Kondisi satu dekade lalu, Unimal telah memiliki 5 (lima) Fakultas dengan 22 (dua puluh dua) Program Studi, dengan total jumlah mahasiswa aktif pada Tahun Akademik 2013/2014 sebanyak $10.279^{1}$ orang.

Memperhatikan data sebagaimana tersaji di bawah ini maka secara umum dapat dilihat prosentase jumlah mahasiswa laki-laki dengan mahasiswi perempuan sebanyak $51 \%: 49 \%$ di Tahun Akademik 2012/2013 dan 48.6\% : $51.4 \%$ di Tahun Akademik 2013/2014. Terdapat peningkatan jumlah mahasiswi perempuan sebanyak 2.4\% di Tahun Akademik 2013/2014. Namun, jika melihat secara khusus maka kita akan menemukan beberapa kondisi khusus pula. Misalnya, pada Fakultas Ilmu Sosial dan Ilmu Politik antara Prodi Ilmu Politik dengan Prodi Ilmu Komunikasi, terlihat perbedaan jumlah mahasiswa laki-laki dengan perempuan yang cukup tinggi.

Pada prodi Ilmu Politik, tahun masuk 2012/2013 terdapat 30 orang mahasiswa dan 11 orang mahasiswa. Di tahun 2013/2014 terdapat 32 mahasiswa dan 18 mahasiswi. Belum dapat diketahui dengan pasti, apakah label bahwa politik adalah domain-nya laki-laki dan perempuan akan sulit berada di wilayah ini menjadi penyebab minimnya jumlah mahasiswi perempuan. Informasi dimaksud dapat dilihat pada tabel berikut:

\footnotetext{
${ }^{1}$ Informasi ini didapat melalui Data Rekap mahasiswa Aktif Unimal, direkap oleh Ka.Bag Kemahasiswaan, per Oktober 2013.
} 
Tabel 1. Keadaan Mahasiswa Aktif Unimal Menurut Fakultas, Program Studi\& Jenis Kelamin pada TA. 2012/2013 dan TA. 2013/2014

\begin{tabular}{|c|c|c|c|c|c|c|c|c|}
\hline \multirow[t]{2}{*}{ No. } & \multirow[t]{2}{*}{ Fakultas } & \multirow[t]{2}{*}{ Program Studi } & \multicolumn{3}{|c|}{$\begin{array}{c}\text { Tahun Masuk } \\
\text { Pada TA. 2012/2013 }\end{array}$} & \multicolumn{3}{|c|}{$\begin{array}{c}\text { Tahun Masuk } \\
\text { Pada TA. 2013/2014 }\end{array}$} \\
\hline & & & LK & PR & JML & LK & PR & JML \\
\hline \multirow{2}{*}{1.} & HUKUM & Ilmu Hukum & 74 & 53 & 127 & 108 & 75 & 183 \\
\hline & \multicolumn{2}{|r|}{ Jumlah } & 74 & 53 & 127 & 108 & 75 & 183 \\
\hline \multirow{6}{*}{2.} & \multirow{5}{*}{$\begin{array}{l}\text { ILMU SOSIAL } \\
\text { \& ILMU } \\
\text { POLITIK }\end{array}$} & 1. Ilmu Administrasi Negara & 53 & 116 & 169 & 60 & 130 & 190 \\
\hline & & 2. Sosiologi & 21 & 43 & 64 & 25 & 51 & 76 \\
\hline & & 3. Ilmu Politik & 30 & 11 & 41 & 32 & 18 & 50 \\
\hline & & 4. Antropologi & 4 & 7 & 11 & 4 & 16 & 20 \\
\hline & & 5. Komunikasi & 47 & 57 & 104 & 38 & 57 & 95 \\
\hline & & Jumlah & 155 & 234 & 349 & 159 & 272 & 431 \\
\hline \multirow{6}{*}{3.} & \multirow{5}{*}{ EKONOMI } & 1. Ilmu Manajemen & 65 & 107 & 172 & 117 & 230 & 347 \\
\hline & & 2. Akutansi & 74 & 116 & 190 & 106 & 181 & 287 \\
\hline & & $\begin{array}{lcc}3 . & \text { Ilmu } & \text { Ekonomi } \\
\text { Pembangunan } & \\
\end{array}$ & 60 & 71 & 131 & 73 & 107 & 180 \\
\hline & & 4. DIII Kesekretariatan & 0 & 24 & 24 & 0 & 18 & 18 \\
\hline & & 5. PP Ilmu Manajemen (S2) & 13 & 9 & 22 & & & \\
\hline & & Jumlah & 212 & 327 & 539 & 296 & 536 & 832 \\
\hline \multirow{8}{*}{4.} & \multirow{7}{*}{ TEKNIK } & 1. T. Sipil & 77 & 11 & 88 & 128 & 31 & 159 \\
\hline & & 2. T. Mesin & 69 & 0 & 69 & 83 & 3 & 86 \\
\hline & & 3. T. Industri & 19 & 18 & 37 & 51 & 41 & 92 \\
\hline & & 4. T. Kimia & 8 & 36 & 44 & 16 & 61 & 76 \\
\hline & & 5. T. Elektro & 57 & 5 & 62 & 77 & 14 & 91 \\
\hline & & 6. T. Arsitektur & 45 & 13 & 58 & 55 & 28 & 83 \\
\hline & & 7. Informatika & 60 & 65 & 125 & 62 & 56 & 118 \\
\hline & & Jumlah & 334 & 148 & 483 & 472 & 234 & 705 \\
\hline \multirow{4}{*}{5.} & \multirow{3}{*}{ PERTANIAN } & 1. Agronomi & 75 & 49 & 124 & 54 & 75 & 129 \\
\hline & & 2. Agribisnis & 40 & 64 & 104 & 54 & 62 & 116 \\
\hline & & 3. Budi Daya Pertanian & 64 & 36 & 100 & 32 & 48 & 80 \\
\hline & & Jumlah & 179 & 149 & 328 & 140 & 185 & 325 \\
\hline \multirow[t]{2}{*}{6.} & PSPD & $\begin{array}{lll}\text { Program } & \text { Studi Pendidikan } \\
\text { Dokter } & & \\
\end{array}$ & 16 & 37 & 53 & 53 & & 53 \\
\hline & \multicolumn{2}{|r|}{ Jumlah } & 16 & 37 & 53 & 53 & & 53 \\
\hline \multirow{2}{*}{\multicolumn{3}{|c|}{$\begin{array}{r}\text { Total Jumlah Mahasiswa } \\
\text { Prosentase Jumlah Mahasiswa (LK \& PR) }\end{array}$}} & 970 & 948 & 1918 & 1228 & 1302 & 2530 \\
\hline & & & $51 \%$ & $49 \%$ & $100 \%$ & $48,6 \%$ & $51,4 \%$ & $100 \%$ \\
\hline
\end{tabular}

Sumber: Data diolah dari Data Mahasiswa Aktif Universitas MalikussalehSemester Ganjil 2013/2014, per Oktober 2013, Biro Akademik \& Kemahasiswaan Unimal.

Berbeda halnya dengan perbandingan jumlah mahasiswa di Prodi Ilmu Komunikasi. Pada tahun akademik 2012/2013 terdapat 47 orang mahasiswa dan 57 orang mahasiswi. Di tahun akademik 2013/2014, jumlah mahasiswa mendaftar sebanyak 38 orang dan mahasiswi sebanyak 57 orang. Walaupun jumlah mahasiswi pada prodi ini jika dibandingkan dengan mahasiswa tidak mencapai nilai lebih dari 50\% nya, namun sebagai salah satu jurusan terfavorit saat ini maka prodi Ilmu Komunikasi lebih didominasi oleh mahasiswi perempuan. Selain data tabel mahasiswa baru TA. 2012/2013 dan TA 2013/2014 di atas, bagian berikut juga akan menayangkan data tabel kondisi jumlah dosen di lingkungan fakultas dan prodi berdasarkan jenis kelamin serta staf kependidikan pada unit kerja lain setingkat lembaga dan UPT yang ada di Unimal. 
Tabel 2. Penyebaran PNS (Dosen dan Staf) di Lingkungan Universitas Malikussaleh pada Tahun 2013 menurut Fakultas, Program Studi dan Jenis Kelamin

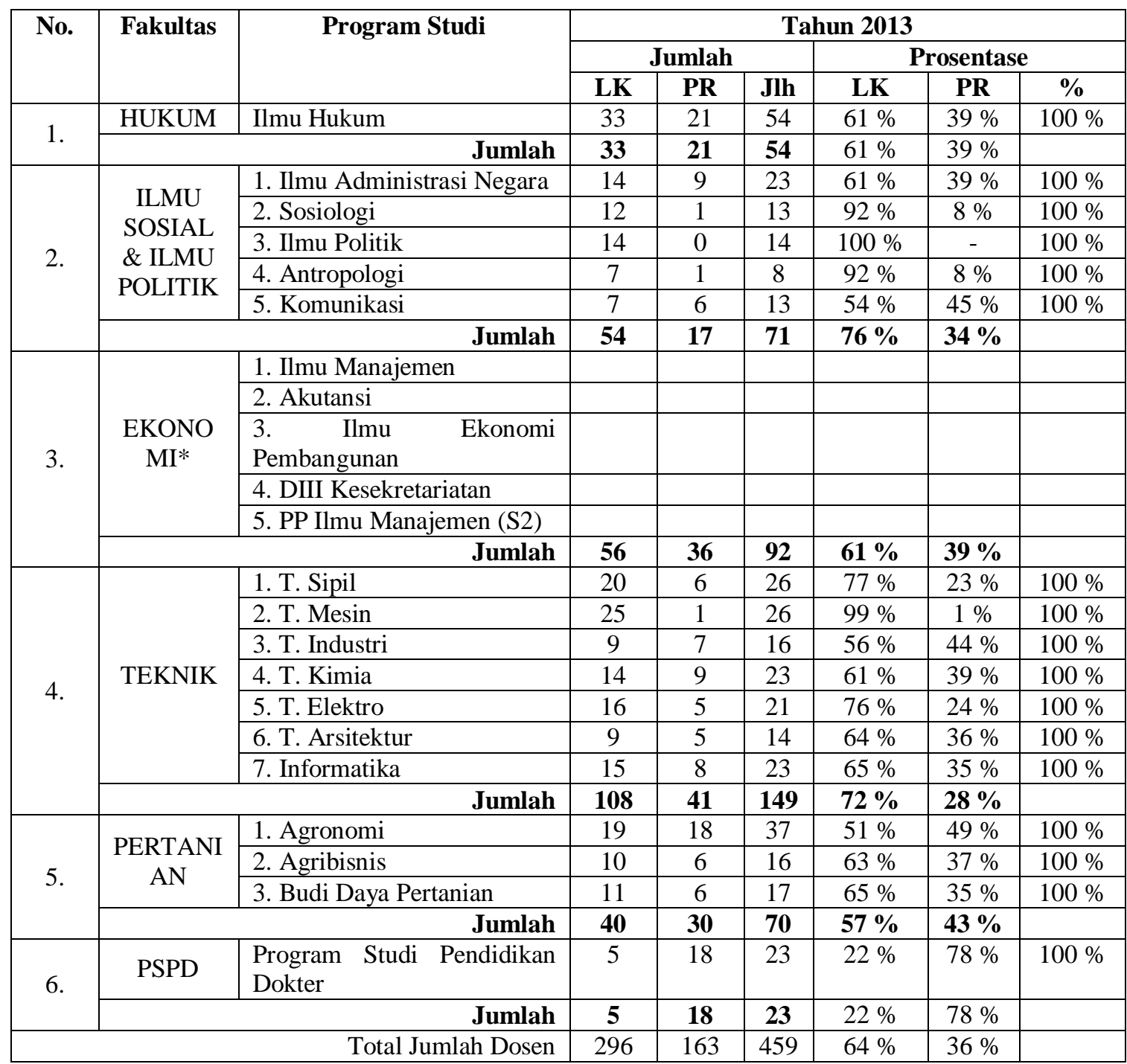

Sumber: Data diolah dari rekapitulasi dosen di tingkat Fakultas/Prodi dan DUK 2013.

* Data terpilah berdasarkan prodi dan jenis kelamin tidak tersedia.

Merujuk pada data sebagaimana disampaikan di atas, maka dapat terlihat komposisi dosen perempuan sebanyak $34 \%$ dengan jumlah total 163 orang, dan dosen laki-laki sebanyak $64 \%$ dengan jumlah 296 orang. Angka yang cukup menonjol terlihat pada prodi Teknik Mesin, PSPD serta 3 prodi di FISIP: Antropologi, Ilmu Politik dan Sosiologi. Tercatat jumlah dosen perempuan yang sangat minim di 5 prodi ini. fakta apa yang ada di balik realitas ini? apakah benar stigma bahwa prodi Teknik Mesin adalah wilayahnya laki-laki? Apakah perempuan tidak mampu atau bahkan berminat untuk bekerja dengan perlengkapan mesin. Data jumlah dosen di prodi teknik mesin maupun ilmu politik juga berbanding lurus dengan jumlah mahasiswanya. Masih ada kesenjangan dari segi jumlah mahasiswa perempuan dibandingkan mahasiswa laki-laki. Pada tahap berikutnya studi ini akan mengeksplorasi lebih dalam keberadaan dosen perempuan yang tercatat di kelima prodi ini dengan melakukan analisis terhadap dinamika relasi antara dosen yang mereka hadapi.

Sejalan dengan data jumlah dosen berdasarkan jenis kelamin, pada bagian berikut juga akan dihadirkan data penyebaran staf pada unit kerja di lingkungan Unimal. Data ini belum 
mencakup jumlah staf honorer dikarenakan masih adanya keterbatasan pada proses pengumpulan data. Namun secara umum dapat disampaikan bahwa komposisi dan jumlah tenaga honorer yang ada di Unimal disebar pada semua unit kerja yang ada sesuai dengan kebutuhan pada masing-masing unit kerja dimaksud.

Tabel 3. Penyebaran Staf menurut Unit Kerja (Lembaga, UPT dan Badan) Berdasarkan Jenis Kelamin di Lingkungan Universitas Malikussaleh pada Tahun 2013

\begin{tabular}{|c|c|c|c|c|c|c|c|c|c|}
\hline \multirow[t]{3}{*}{$\begin{array}{l}\mathbf{N} \\
\mathbf{0}\end{array}$} & \multirow[t]{3}{*}{ Unit Kerja } & \multirow{2}{*}{\multicolumn{2}{|c|}{$\begin{array}{c}\text { Nama \& Jenis Kelamin Ketua/ } \\
\text { Kepala Unit Kerja }\end{array}$}} & \multicolumn{6}{|c|}{$\begin{array}{c}\text { Jumlah \& Prosentase Staf di Lingkungan } \\
\text { Lembaga pada Tahun } 2013\end{array}$} \\
\hline & & & & \multicolumn{3}{|c|}{ Jumlah* } & \multicolumn{3}{|c|}{ Prosentase } \\
\hline & & Nama & $\begin{array}{l}\text { Jenis } \\
\text { Kelamin }\end{array}$ & LK & PR & Jlh & LK & $\mathbf{P R}$ & $\%$ \\
\hline 1. & LPPM & $\begin{array}{l}\text { Yulius Dharma, } \\
\text { S.Ag., M.Si }\end{array}$ & Laki-laki & 9 & 2 & 11 & $82 \%$ & $18 \%$ & $100 \%$ \\
\hline 2. & $\begin{array}{l}\text { UPT. } \\
\text { Perencanaan }\end{array}$ & $\begin{array}{l}\text { T.M. Ridwan, ST., } \\
\text { MT }\end{array}$ & Laki-laki & 5 & 2 & 7 & $71.5 \%$ & $28.5 \%$ & $100 \%$ \\
\hline 3. & UPT. Puskom** & Rizal, S.Si., M.IT & Laki-laki & & & & & & $100 \%$ \\
\hline 4. & $\begin{array}{l}\text { UPT. } \\
\text { Perpustakaan }\end{array}$ & $\begin{array}{l}\text { Dahlan Abdullah, } \\
\text { S.Kom., M.Kom }\end{array}$ & Laki-laki & 3 & 7 & 10 & $30 \%$ & $70 \%$ & $100 \%$ \\
\hline 5. & $\begin{array}{l}\text { UPT. Unimal } \\
\text { Press }\end{array}$ & Al Chaidar, S.IP & Laki-laki & 2 & 0 & 2 & $100 \%$ & $0 \%$ & $100 \%$ \\
\hline 6. & $\begin{array}{l}\text { Badan Penjamin } \\
\text { Mutu** }\end{array}$ & $\begin{array}{l}\text { Dr. Muhammad, } \\
\text { ST., M.Sc }\end{array}$ & Laki-laki & & & & & & \\
\hline
\end{tabular}

Sumber: Data diolah dari berbagai Unit Kerja, tahun 2013

* Data staf tidak termasuk staf honorer.

** Data belum dapat diakses.

Membaca data tersaji di atas terlihat bahwa masih perlu dieksplorasi lebih dalam terkait dengan alasan maupun persyaratan penempatan karyawan. Pada semua unit kerja selain Fakultas dan Prodi dipimpin oleh staf laki-laki - yang kesemuanya juga adalah dosen di lingkungan Unimal. Apakah terdapat persyaratan khusus untuk menempati posisi ketua/kepala pada unit-unit tersebut? Bagaimana dengan perempuan-perempuan yang memenuhi persyaratan? Apakah pernah dipertimbangkan? Apakah perspektif sensitifitas gender turut dipertimbangkan oleh pimpinan Unimal dalam memutuskan kepala unit kerja dimaksud?

Pada unit kerja LPPM dipimpin oleh laki-laki dan terdapat 10 (sepuluh) orang staf PNS dari dosen dan karyawan. 4 (empat) orang kepala pusat studi, 3 (tiga) diantaranya laki-laki. Terdapat 1 (satu) orang staf perempuan yang menjabat sebagai Kasubag Umum dan Keuangan. Selanjutnya, jika merujuk pada data staf di unit kerja UPT Perpustakaan dan mengunjungi langsung perpustakaan Universitas Malikussaleh yang terletak di kampus utama Reuleut kita juga akan dilayani oleh mayoritas staf perempuan. Apakah stigma ketelitian, kerapian dalam perawatan buku-buku perpustakaan menjadi klaim untuk menempatkan perempuan. Wawancara peneliti dengan Kasubag Tata Usaha ${ }^{2}$ mendapatkan informasi, bahwa hasil evaluasi inspektorat tahun 2011 mempertanyakan kebijakan penempatan perempuan yang mayoritas di unit perpustakaan, namun tampaknya hasil dari evaluasi tersebut belum ditindaklanjuti oleh pimpinan maupun dilakukan evaluasi internal pada unit kerja dimaksud.

Dari gambaran data sebagaimana telah disampaikan, Unimal perlu melakukan evaluasi yang komprehensif atas isu kesetaraan gender ini. selain terkait dengan komposisi dan penyebaran staf pada unit kerja juga melakukan evaluasi terhadap program-program yang direncanakan dan dianggarkan dengan aspek kesetaraan gender.

Pada beberapa lokasi kampus, misalnya di Fakultas Hukum, FISIP, sebahagian lokasi perkuliahan kampus Fakultas Ekonomi, Biro Reuleut - mahasiswi, dosen dan staf perempuan mendapatkan hambatan akses dan fasilitas untuk dapat secara nyaman melaksankan ibadah sholat dan

${ }^{2}$ Wawancara dengan Ibu Tiainsyah, SH., Kasubag TU UPT. Perpustakaan, 12 Oktober 2013. 
berwudhu dikarenakan tidak adanya fasilitas tempat berwudhu yang representatif seperti ruang tersendiri, terpisah dari fasilitas wudhu laki-laki dan tertutup. Belum ada perlindungan dan kenyamanan bagi perempuan untuk melakukan wudhu dengan membuka jilbabnya. Sarana lain yang juga perlu mendapatkan perhatian oleh pimpinan Unimal adalah toilet, tangga, ruang terbuka hijau, fasilitas kebersihan di lingkungan kampus juga fasilitas penitipan anak.

Khusus untuk kondisi tangga dan toilet pada beberapa lokasi kampus belum mencerminkan adanya pemenuhan kebutuhan yang berbeda antara laki-laki dengan perempuan. Pada tangga belakang di Kampus Lancang Garam - yang biasanya dimanfaatkan oleh Fakultas Hukum dalam proses belajar mengajar kelas Reguler B - telah dilaporkan berkali-kali kejadian jatuhnya mahasiswi maupun dosen perempuan dikarenakan bidang tangga yang terlalu sempit dan gelap.

Pengalaman pribadi anggota perempuan pada tim penelitian ini menjumpai kondisi yang mengkhawatirkan ketika memanfaatkan fasilitas toilet di wilayah kampus Bukit Indah, baik di lingkungan Jl. Kalimantan - wilayah Fakultas Ekonomi, maupun di lingkungan Jl. Jawa pada Fakultas Hukum. Selain buruknya kualitas sanitasi kebersihan pada masing-masing toilet, yang juga perlu mendapatkan perhatian adalah keamanan di toilet. Beberapa toilet tidak memiliki pengamanan kunci pada pintunya juga lokasi toilet. Walaupun tidak berada jauh dari ruang perkuliahan, namun dikarenakan setting ruangan toilet sebelum dimanfaatkannya rumah-rumah tinggal ini sebagai ruang perkuliahan, maka muncul kekhawatiran: (1) lokasinya di luar ruang perkuliahan, biasanya di samping garasi (dulunya dimanfaatkan sebagai toilet pekerja rumah tangga); (2) tidak terdapat cukup penerangan di area toilet; dan (3) adanya ruang-ruang kecil yang kadangkala menimbulkan perasaan tidak nyaman dan aman. Pertanyaan - pertanyaan seperti "apakah tidak ada yang ngintip?" kerap kali timbul dalam benak mahasiswi. ${ }^{3}$

Senada dengan observasi dan diskusi terkait dengan fasilitas toilet di lingkungan kampus, salah seorang mahasiswi juga menyampaikan "... dulu ada WC untuk perempuan, tapi sekarang sudah tidak ada, WC-nya sudah rusak. Jadi kalau mau ke WC minta ditemanin sama kawan karena WC-nya gabung sama laki-laki. dan WC-nya kotor tidak bersih"4.

Wawancara lain yang peneliti lakukan kepada salah seorang mahasiswi terkait dengan fasilitas kampus menjumpai jawaban berikut, "... menurut saya kondisinya belum baik, ruangan belajar sering kotor dan panas, cuma sebagian ruangan yang ada kipas angin. Ruangan belajar jadi kurang nyaman dan pengap. Apalagi WC susah sekali disini, tidak ada WC yang dikhususkan baik untuk perempuan atau laki-laki. Kalau kami mau buang air kecil atau air besar kami harus menahannya, tapi kadangkadang kami numpang ditempat orang". 5

\section{Kajian Pustaka}

\section{Dinamika Relasi Gender di Kalangan Civitas Akademika Universitas Malikussaleh}

Persoalan gender maupun persoalan perempuan sebagai pemimpin dalam konteks keagamaan juga telah menjadi perdebatan terus menerus. Di satu sisi, persoalan gender dianggap sebagai satu konteks yang memungkinkan untuk didiskusikan, ditafsirkan dengan menyesuaikan pada konteks sosial kemasyarakatan yang ada. Namun di sisi lain, membicarakan tentang gender; keberadaan perempuan dan laki-laki maka tertutup kemungkinan adanya pergantian peran. Untuk itu, kiranya kita dapat merujuk kembali pada 2 (dua) teori besar yang ada terkait dengan kenyataan biologis yang membedakan 2 (dua) jenis kelamin ini, teori nature dan teori nurture.

Teori nature menganggap perbedaan peran laki-laki dan perempuan bersifat kodrati (nature). Anatomi biologi laki-laki yang berbeda dengan perempuan menjadi faktor utama dalam penentuan peran sosial kedua jenis kelamin ini. Laki-laki memerankan peranan sosial di dalam karena dianggap lebih potensial, lebih kuat dan lebih produktif. Organ reproduksi dinilai membatasi ruang gerak perempuan, seperti hamil, melahirkan dan menyusui, sementara laki-laki tidak mempunyai fungsi reproduksi tersebut. Perbedaan ini melahirkan pemisahan fungsi tanggungjawab antara laki-laki dan

\footnotetext{
${ }^{3}$ Wawancara dengan sekelompok mahasiswi penempuh matakuliah Pengantar Hukum Bisnis, Jurusan IESP, Fakultas Ekonomi, 4 April 2013.

${ }^{4}$ Musliana (salah seorang mahasiswi di lingkungan kampus Bukit Indah), Wawancara 5 September 2013.

${ }^{5}$ Wawancara dengan Desiana, Mahasiswi FH - Unimal, di Lhokseumawe, 9 September 2013.
} 
perempuan. Laki-laki berperan di sektor publik dan perempuan mengambil peran di sektor domestik. Teori nurture beranggapan perbedaan relasi gender laki-laki dan perempuan tidak ditentukan oleh faktor biologis melainkan konstruksi masyarakat. Dengan kata lain, peran sosial yang selama ini dianggap baku dan difahami sebagai doktrin keagamaan, menurut penganut faham nurture sesungguhnya bukanlah kehendak Tuhan dan tidak juga sebagai produk determinasi biologis melainkan sebagai produk konstruksi sosial (social construction). Banyak nilai-nilai bias gender yang terjadi di dalam masyarakat dianggap disebabkan oleh faktor biologis tapi sesungguhnya tidak lain adalah konstruksi budaya. ${ }^{6}$

Quraish Shihab dalam pengantar buku Nasaruddin Umar menyampaikan bahwa menguraikan persoalan kemitraan laki-laki dan perempuan dengan merujuk sumber ajaran, dapat menimbulkan beda pendapat, apalagi (dalam) memahami teks-teks keagamaan, bahkan teks apapun, dipengaruhi oleh banyak faktor. Bukan saja tingkat pengetahuan tetapi juga latar belakang pendidikan, budaya serta kondisi sosial masyarakat.

Posisi perempuan masih sering diperhadap-hadapkan dengan posisi laki-laki. Posisi perempuan selalu dikaitkan dengan lingkungan domestik yang berhubungan urusan dengan keluarga dan kerumahtanggaan. Sementara posisi laki-laki sering dikaitkan dengan lingkungan publik yang berhubungan dengan urusan-urusan di luar rumah. Dalam truktur sosial, posisi perempuan yang demikian sulit mengimbangi posisi laki-laki. Perempuan yang ingin berkiprah di lingkungan publik, masih sulit melepaskan diri dari tanggungjawabnya di lingkungan domestik. Perempuan dalam hal ini kurang berdaya untuk menghindar dari beban ganda tersebut karena tugasnya sebagai pengasuh anak sudah merupakan persepsi budaya secara umum. Kontrol budaya agaknya lebih ketat kepada perempuan daripada laki-laki. ${ }^{7}$

Gender sendiri difahami sebagai pembedaan peran, status, tanggungjawab dan pembagian kerja laki-laki dan perempuan yang ditetapkan masyarakat maupun budaya berdasarkan jenis kelamin dan merupakan bentukan manusia. Pembedaan ini sering menciptakan ketidakadilan, khususnya bagi kelompok miskin dan juga perempuan. Contoh ketidak-adilan yang terjadi diantaranya adalah, adanya perbedaan upah antara laki-laki dan perempuan, akses dan penguasaan perempuan terhadap sumber daya alam rendah, perempuan dan kelompok miskin tidak dilibatkan dalam proses pengambilan keputusan dan lain sebagainya.

Terkait dengan posisi relasi antara perempuan dengan laki-laki dalam pembagian kerja, maka secara umum biasanya kita akan melihat fenomena bahwa (1) laki-laki akan lebih dominan dari perempuan pada masyarakat nomad; (2) perempuan akan diberikan peranan yang lebih mandiri pada masyarakat agraris dan (3) pada masyarakat industri maju, maka penguasaan atas teknologi canggih dan kemampuan bekerja akan lebih diutamakan tanpa memandang jenis kelaminnya. Kondisi Unimal tampaknya dapat kita kategorikan pada kelompok ketiga. Bahwa sebagai institusi pendidikan maka selayaknya penguasaan dan skill yang tinggi terhadap teknologi dan informasi menajdi tuntutan, namun tidak dapat dipungkiri bahwa setting sosio kultural kita berada pada masyarakat agraris yang memberikan beban dan peranan yang lebih bagi perempuan; tidak hanya di bidang pekerjaan misalnya pengurusan sawah, ladang maupun kebun; tetapi juga beban-beban pekerjaan domestik.

Untuk itu, ketika membicarakan relasi dan dinamika yang ada - sebenarnya - tidak hanya membicarakan tentang apakah perempuan diberikan akses, perempuan diberikan peluang dan kesempatan yang sama dan berimbang dengan laki-laki untuk dapat misalnya menduduki posisi tertentu tetapi juga membicarakan apakah kebijakan atau program-program pembangunan di Unimal telah melibatkan secara adil bagi perempuan maupun laki-laki dalam menyuarakan kebutuhannya; apakah perempuan dan laki-laki dapat berpartisipasi dalam pengambilan keputusan?. Selain itu, identifikasi terhadap bagaimana kebijakan yang ada di Unimal memberikan kesempatan penguasaan yang sama kepada perempuan dan laki-laki untuk mengontrol sumberdaya pembangunan dan juga mengidentifikasi apakah kebjakan ataupun program-program di Unimal telah memberikan manfaat yang adil bagi perempuan dan laki-laki.

\footnotetext{
${ }^{6}$ Lihat lebih lanjut pada pengantar penerbit buku Nasaruddin Umar, Argumen Kesetaraan Gender -Perspektif Al Qur'an, Paramadina, Jakarta, 1999, halaman xxi - xxii.

${ }_{7}^{7}$ Nasaruddin Umar, op. cit., Jakarta: Paramadina, 1999, hlm. 8687.
} 
Salah seorang dosen senior dan juga Sekretaris Senat Universitas ${ }^{8}$ menyampaikan pandangannya terkait dengan hal ini. Menurut beliau "dinamika relasi antar civitas akademika lakilaki dengan perempuan sangat rendah. Keterlibatan perempuan dalam jabatan struktural, fungsional, dan teamwork atau kepanitiaan masih kurang. Keterlibatan perempuan belum berdasarkan 'affirmative action', tetapi realitas apa adanya. Sehingga peran perempuan sangat individual, tergantung individu perempuan tertentu yang memang cenderung aktif dan kreatif".

Senada dengan pandangan di atas, beberapa dosen dan staf perempuan di Fakultas Hukum dan Fisip juga menyampaikan hal senada. Bahwa walaupun tampaknya tidak ada peraturan atau penolakan-penolakan atas keterlibatan perempuan secara langsung, sebenarnya akan sangat bergantung pada perempuannya sendiri. ${ }^{9}$ Menurut mereka, tidak tepat jika beban ganda perempuan itu karena urusan domestiknya perempuan, bagi mereka yang utama adalah urusan yang di rumah. Mereka meyakini bahwa sebenarnya kondisi ini akan sangat bergantung pada manajemen waktu yang dimiliki oleh perempuan. Kondisinya adalah - kedua urusan; di rumah dan di kantor - masingmasingnya adalah tugas dan tanggungjawab yang melekat pada perempuan. Perempuan harusnya bisa mengatur urusan rumah tangga, dikerjakan dan diselesaikan di rumah, dan menyelesaikan urusan kantor pada waktu kerja. Semua beban kerja yang ada pada dasarnya adalah kontraprestasi dari penghasilan yang diterima setiap bulannya.

Diakui bahwa dalam kapasitas mereka yang dipilih oleh Dekan untuk menjabat pada posisiposisi tertentu maka beban tugas juga menjadi bertambah, namun apa pertimbangan yang melatarbelakngi Dekan memilih perempuan sebagai pejabat atau pelaksana tugas tertentu di unit kerjanya akan menjadi menarik untuk didalami.

Pada bagian berikut dari tulisan ini akan memberikan eksplorasi terhadap keempat faktor sebagaimana telah disampaikan sebelumnya: (1) akses, (2) partisipasi, (3) kontrol dan (4) manfaat dalam mencermati dinamika relasi gender di kalangan civitas akademika Unimal, dengan menghadirkan data - data kuantitatif yang dapat diakses disandingkan dengan eksplorasi terhadap data dimaksud.

Tabel 4. Pimpinan/Pejabat Rektor dan Pembantu Rektor Universitas Malikussaleh Menurut Unit Tugas dan Jenis Kelamin

\begin{tabular}{|c|l|c|c|c|c|}
\hline \multirow{2}{*}{ No. } & \multirow{2}{*}{ Jenis Jabatan } & \multicolumn{2}{c|}{ Periode } & \multicolumn{2}{c|}{ Periode } \\
\cline { 3 - 6 } & & LK & PR & LK & PR \\
\hline 1. & Rektor & 1 & - & 1 & - \\
\hline 2. & Pembantu Rektor 1 & 1 & - & 1 & - \\
\hline 3. & Pembantu Rektor 2 & 1 & - & 1 & - \\
\hline 4. & Pembantu Rektor 3 & 1 & - & 1 & - \\
\hline 5. & Pembantu Rektor 4 & 1 & - & 1 & - \\
\hline & Jumlah & 5 & - & 5 & - \\
\hline
\end{tabular}

Sumber: Sub. Bagian Kepegawaian Universitas Malikussaleh

Berdasarkan data tersedia pada tabel 1 di atas, terlihat bahwa kepemimpinan Unimal khususnya pada tingkat top level management - Rektor dan Pembantu Rektor pada dua periode kepemimpinan ini tidak diwarnai dengan keberadaan perempuan sebagai salah satu pemimpin. Tidak pernah tercatat juga adanya perempuan yang mencalonkan diri sebagai Rektor. Kenapa atau apa yang melatarbelakngi hal ini? apakah prasyarat ${ }^{10}$ atau kualifikasi untuk menjadi Rektor yang tidak dapat ditempuh oleh perempuan?

Jika merujuk pada Pasal 45 Statuta Unimal mengatur persyaratan menjadi Rektor sebagaimana

\footnotetext{
${ }^{8}$ Wawancara dengan T. Nazaruddin, di Lhokseumawe, tanggal 27 September 2013.

${ }^{9}$ Wawancara dengan Ibu Manfarisyah (dosen perempuan senior di FH), Ibu Malahayati (Ketua Bagian Hukum Tata Negara pada FH), dan Ibu Rosmanita (Kabag TU Fak. Hukum), 19 Oktober 2013 dan Ibu Maryam (Ka. Prodi IAN - FISIP), 1 November 2013.

${ }^{10}$ Lihat lebih lanjut pada Statuta Unimal.
} 
yang akan disajikan berikut, maka poin yang manakah yang menjadi penghalang secara internal maupun eksternal bagi perempuan untuk mengajukan pencalonannya?

1) Menyatakan Kesediaan Secara Tertulis Untuk Menjadi Rektor;

2) Hasil Pertimbangan Rapat Senat Unimal;

3) Beriman dan Bertaqwa;

4) Memiliki Moralitas dan Kemampuan Akademik Yang Tinggi;

5) Memiliki Kreativitas dan Produktivitas dalam Menjalin Hubungan Kerjasama dengan Luar dan Pihak Dalam Unimal;

6) Berpendidikan Minimal Sarjana;

7) Berkepribadian Yang Baik, Beretika, Berwibawa, Rapi dan Bersih;

8) Minimal Telah Mengajar 6 (Enam) Tahun di Perguruan Tinggi;

9) Sanggup Bertugas Penuh Sebagai Pimpinan Serta Harus Hadir Selama Jam Kerja;

10) Tidak Merangkap Sebagai Pimpinan Pada Perguruan Tinggi Lain; dan

11) Mempunyai Jabatan Fungsional Dosen Minimal Lektor Kepala.

\section{Pembahasan}

Tabel 5. Pimpinan Fakultas di Lingkungan Universitas Malikussaleh Menurut Unit Tugas dan Jenis Kelamin

\begin{tabular}{|c|c|c|c|c|c|c|c|c|c|c|c|}
\hline \multirow[t]{3}{*}{ No. } & \multirow[t]{3}{*}{ Jenis Jabatan } & \multicolumn{10}{|c|}{ Tahun 2013} \\
\hline & & \multicolumn{2}{|c|}{$\mathrm{FH}$} & \multicolumn{2}{|c|}{ FE } & \multicolumn{2}{|c|}{ FISIP } & \multicolumn{2}{|c|}{ FT } & \multicolumn{2}{|c|}{ FP } \\
\hline & & LK & PR & LK & PR & LK & PR & LK & PR & LK & PR \\
\hline 1. & Dekan & 1 & - & 1 & - & 1 & - & 1 & - & 1 & - \\
\hline 2. & Pembantu Dekan 1 & 1 & - & 1 & - & 1 & - & 1 & - & 1 & - \\
\hline 3. & Pembantu Dekan 2 & 1 & - & 1 & - & - & 1 & 1 & - & 1 & - \\
\hline 4. & Pembantu Dekan 3 & - & 1 & 1 & - & 1 & - & 1 & - & 1 & - \\
\hline 5. & Pembantu Dekan 4 & 1 & - & 1 & - & - & 1 & 1 & - & 1 & - \\
\hline & Jumlah & 4 & 1 & 5 & 0 & 3 & 2 & 5 & 0 & 5 & 0 \\
\hline
\end{tabular}

Sumber: Sub. Bagian Kepegawaian Universitas Malikussaleh

Tabel di atas memberikan gambaran bahwa kepemimpinan perempuan di level tertinggi pada unit kerja fakultas adalah laki-laki. Seperti halnya pencalonan rektor, pada tingkat dekanat juga tidak tercatat adanya pencalonan dari dosen perempuan, kecuali di Fakultas Hukum pada proses pemilihan dekan periode 2011 - 2015. Secara formil, tidak tercatat bahwa yang bersangkutan ikut mendaftarkan diri dan memberikan pernyataan kesediaannya sebagai calon dekan. Hal ini dikarenakan - menjelang waktu terakhir pengajuan kesediaan calon - terlihat tidak terpenuhinya kuota calon sebanyak minimal 3 (tiga) orang. Untuk itu dan atas dukungan dari beberapa orang kolega, yang bersangkutan mengajukan diri untuk mengisi borang pencalonan sebagai dekan. Sampai akhirnya menjelang jam akhir penutupan pencalonan terdapat satu pendaftaran dari kandidat laki-laki.

Terkait dengan hal ini, konfirmasi secara langsung telah dilakukan dengan ybs (ES) dan beliau menyampaikan bahwa secara pribadi beliau sadar pada saat mengajukan inisiatif pencalonan dengan tujuan untuk menjaga agar pemilihan dapat terus dilaksanakan tanpa penundaa. Beliau juga menyadari bahwa posisinya pada saat itu, jika merujuk pada tradisi Aceh diistilahkan sebagai "intat linto": mengantar pengantin laki-laki, artinya hanya untuk sekedar memenuhi aturan jumlah calon minimal. Istilah ini juga lazim didengar pada proses pengadaan barang dan jasa pemerintahan yang menggambarkan situasi banyaknya para peminat tender namun masing-masing mereka sudah memahami bahwa keberadaannya hanya sebagai pelengkap; dikarenakan pemenang tendernya sendiri sudah dapat ditentukan dan biasanya si calon memiliki modal dan kekuatan lebih.

Jika pada level Rektor dan Dekan tidak tercatat adanya perempuan, namun di level pembantu dekan - khususnya pada periode saat ini - telah terdapat 3 (tiga) orang perempuan: 1 (satu) orang dari Fakultas Hukum dan 2 (dua) orang dari FISIP yang diajukan oleh Dekan terpilih dan disetujui oleh 
senat fakultas.Di lingkungan FISIP, dekan terpilih ${ }^{11}$ dalam wawancara menyampaikan bahwa memilih perempuan sebagai pembantu dekan maupun ketua prodi di bawah pimpinannya adalah (memang) diniatkan oleh yang bersangkutan. "... sebenarnya ini adalah konsep awal saya. (1) Pembantu dekan tidak boleh semuanya didominasi laki-laki, dan (2) tentunya memperhatikan aspek kemampuan pribadi dari calonpembantu dekan". Dalam penjelasannya beliau menyampaikan bahwa berdasarkan asumsi dan pengalaman pribadi beliau "sepertinya perempuan lebih baik, lebih jujur dan bertanggungjawab dibandingkan laki-laki dalam penyelesaian tugas. Banyak orang laki yang lalee (lalai) - biasanya bilang sibuk; beralasan bahwa dosen tidak hanya wajib masuk kampus, tapi juga wajib melaksanakan tridharma lainnya, tapi sibuknya tidak jelas. Ketika ditagihkan laporan pelaksanaan tridharmanya juga tidak mampu menunjukkan. Yang ada malah kebanyakan sibuk di warung kopi. Padahal pekerjaan kita banyak". Pada saat ini beliau mencontohkan beban kerja pada saat pengurusan akreditasi prodi yang kadangkala mengalami hambatan ketika banyak dosen yang menyepelekan tugas ini dengan berbagai alasan, padahal kepentingan dosen dan mahasiswa pada prodi bersangkutan sangat besar atas peningkatan akreditasi tersebut.

Bagaimana dekan memilih calon pembantu dekannya, biasanya tidak terlepas dari pertimbangan - apakah - yang bersangkutan konstituen dekan terpilih?. Pertimbangan ini tidak dipungkiri oleh Dekan Fisip dikarenakan sebagai dekan beliau akan bertanggungjawab dalam mencapai visi dan misinya pada saat pencalonan. Dengan demikian, kandidat pembantu dekan dan pelaksana tugas lainnya juga harus yang mau bersama-sama bekerja mencapai visi misi tersebut.

Terkait dengan keberadaan perempuan sebagai pejabat, Fauzi tidak memungkiri adanya kelemahan-kelemahan dari yang bersangkutan. Kelemahan ini menurut beliau adalah karena perempuan-perempuan yang ada di Unimal pada usia produktif, sehingga sebagai pimpinan beliau seringkali berhadapan dengan ijin maupun cuti terkait dengan masa melahirkan maupun kepentingankepentingan bayi. Terkadang, baru satu tahun lebih melahirkan sudah mulai hamil lagi anak kedua, anak ketiga dan seterusnya.

Menarik untuk dapat mengeksplorasi "kelemahan" yang dimaksud oleh salah satu pejabat di Unimal terkait dengan fungsi reproduksi perempuan yang merupakan hal kodrati. Pada posisi manakah sensitifitasnya terhadap kesetaraan gender? Di satu sisi pengalaman pribadinya melatarbelakangi sikapnya dalam memilih perempuan sebagai pembantu dekan, namun di sisi lain tampaknya beliau memberikan catatan khusus atas kebutuhan reproduksi perempuan. Cerminan ini sebenarnya dapat ditemukan di banyak institusi dan pada sikap mental pejabat; adanya dualisme pikiran dan sikap, di satu sisi merasa bahwa memberikan tugas kepada perempuan akan memberikan keuntungan dikarenakan perempuan dianggap mampu bertanggungjawab atas penyelesaian beban kerja, namun di sisi lain - seandainya - ada laki-laki yang juga mampu mengerjakan tugas-tugas yang dibebankan sampai dengan selesai, maka peluang bagi laki-laki untuk mendapatkan jabatan tersebut pasti lebih besar dibandingkan perempuan.

Studi ini juga mengeksplorasi pendapat dosen di lingkungan Unimal terkait dengan relasi gender yang ada. Salah seorang dosen laki-laki dari Fakultas Ilmu Sosial dan Ilmu Politik (FISIP) menyampaikan bahwa dalam pandangannya penyelenggaran pendidikan khususnya di FISIP telah menunjukkan keadilan gender, dikarenakan telah menerapkan prinsip keadilan dan persamaan serta kesetaraan antara laki-laki dan perempuan. Proses penyelenggaraan kepemimpinan juga tidak menunjukkana adanya diskriminasi gender. Menurut beliau, kondisi ini dapat dilihat dari distribusi dan komposisi civitas akademika khususnya pejabat, dosen bahkan pegawai. Khusus untuk pejabat atau pemimpin di lingkungan FISIP sudah mencerminkan kesetaraan gender misalnya; Pembantu Dekan II (Ainol Mardhiah), Pembantu Dekan IV (Ti Aisyah), Ketua Jurusan IAN (Maryam), Sekretaris Jurusan IAN (Hafni), Sekretaris prodi Komunikasi (Ade Muana) adalah pejabat dijabat oleh perempuan. Di lingkungan staf juga menunjukkan adanya kondisi bahwa staf perempuan lebih dominan dari segi jumlah. ${ }^{12}$

Jika pada lingkungan FISIP telah menunjukkan gambaran general sebagaimana disampaikan pada bagian di atas, maka kondisi yang ada di lingkungan Fakultas Hukum juga kiranya dapat menjadi bagian dari pembahasan pada tulisan ini. Dekan terpilih sering menyampaikan bahwa beliau

\footnotetext{
${ }^{11}$ Wawancara dengan Fauzi, S.Sos., MA - Dekan FISIP Unimal, di Lhokseumawe, tanggal 2 November 2013.

12 Wawancara dengan Abidin Nurdin, salah seorang dosen laki-laki di Unit Kerja FISIP, tanggal....
} 
mempertimbangkan beberapa hal khusus yang akan diterapkannya untuk menyusun kriteria dan komposisi calon pembantu dekan-nya. Kriteria dimaksud adalah calon-calon yang diajukan (1) mempertimbangkan kondisi alumni dan non alumni; (2) mempertimbangkan perimbangan jenis kelamin: laki-laki dan perempuan, dan (3) mempertimbangkan pemilih non-pemilih. ${ }^{13}$

Kondisi ini apakah mencerminkan adanya perspektif - Dekan Fakultas Hukum dan Dekan FISIP- yang telah berkesetaraan gender? Atau dalam kondisi sebaliknya di lingkungan Fakultas Ekonomi, Fakultas Teknik dan Fakultas Pertanian yang sama sekali tidak memiliki Pembantu Dekan perempuan apakah mencerminkan tidak adanya perspektif kesetaraan gender?

Untuk dapat memberikan gambaran kuantitatif terhadap kesetaraan gender di lingkungan unit kerja fakultas, maka pada bagian berikut akan disajikan data pejabat di lingkungan fakultas mulai dari Dekan sampai dengan Kepala Lab.

Tabel 6. Pejabat di Lingkungan Fakultas Hukum

\begin{tabular}{|c|c|c|c|c|}
\hline \multirow[t]{2}{*}{ No. } & \multirow[t]{2}{*}{ Jabatan } & \multirow[t]{2}{*}{ Nama } & \multicolumn{2}{|c|}{ Jenis Kelamin } \\
\hline & & & LK & PR \\
\hline 1. & Dekan & Sumiadi, SH., M.Hum & $\checkmark$ & - \\
\hline 2. & Pembantu Dekan & Zulfan, SH., M.Hum & $\checkmark$ & - \\
\hline 3. & Pembantu Dekan & Jumadiah, SH., MH & $\checkmark$ & - \\
\hline 4. & Pembantu Dekan & Herinawati, SH., M.Hum & - & $\checkmark$ \\
\hline 5. & Pembantu Dekan & Muhammad Hatta, SH., L.LM & $\checkmark$ & \\
\hline 6. & Kepala Bagian Tata Usaha & Rosmanita, $\mathrm{SH}$ & & $\checkmark$ \\
\hline 7. & Kasubag Adm. Umum \& Keuangan & Rohaya, Amd & & $\checkmark$ \\
\hline 8. & $\begin{array}{l}\text { Kasubag Akademik \& } \\
\text { Kemahasiswaan }\end{array}$ & Jamaluddin, SH & $\checkmark$ & - \\
\hline 9. & Kepala Laboratorium Hukum & M. Nasir, SH., L.LM & $\checkmark$ & - \\
\hline 10. & $\begin{array}{l}\text { Kepala Pusat Dokumentasi Ilmu } \\
\text { Hukum (PDIH) }\end{array}$ & Husni, SH., M.H & $\checkmark$ & - \\
\hline 11. & Ketua Bagian Hukum Perdata & Laila M. Rasyid, SH., M.Hum & - & $\checkmark$ \\
\hline 12. & Sekretaris Bag. Hukum Perdata & Nasrianti, SH., M.Hum & - & $\checkmark$ \\
\hline 13. & Ketua Bagian Hukum Pidana & Johari, SH., MH & $\checkmark$ & - \\
\hline 14. & Sekretaris Bag. Hukum Pidana & Joelman Subaidi, SH., MH & $\checkmark$ & - \\
\hline 15. & Ketua Bagian Hukum Tata Negara & Malahayati, SH., L.LM & - & $\checkmark$ \\
\hline 16. & Sekretaris Bag. Hukum Tata Negara & Nuribadah, SH., MH & - & $\checkmark$ \\
\hline & & Jumlah & 9 & 7 \\
\hline & & Jumlah Total & \multicolumn{2}{|c|}{16} \\
\hline & & Prosentase & $56 \%$ & $44 \%$ \\
\hline
\end{tabular}

Sumber: Struktur Organisasi Fakultas Hukum

Tabel 7. Pejabat di Lingkungan Fakultas Ilmu Sosial \& Ilmu Politik

\begin{tabular}{|c|l|l|c|c|}
\hline No. & \multicolumn{1}{|c|}{ Jabatan Nama } & \multicolumn{2}{c|}{ Jenis Kelamin } \\
\cline { 3 - 5 } & & & LK & PR \\
\hline 1. & Dekan & Fauzi, S.Sos., MA & $\checkmark$ & - \\
\hline 2. & Pembantu Dekan 1 & M. Husen MR, SP., MA & $\checkmark$ & - \\
\hline 3. & Pembantu Dekan 2 & Ainol Mardhiah, S.A., M.Si & - & $\checkmark$ \\
\hline
\end{tabular}

\footnotetext{
${ }^{13}$ Informasi ini penulis ketahui dari berbagai diskusi dengan Dekan terpilih, Sumiadi, SH., M.Hum. Dari 4 (empat) posisi pembantu dekan, terdapat 4 (empat) orang calon pembantu dekan yaitu: Ibu Elidar Sari, SH., MH dan Ibu Malahayati, SH., LLM sebagai kandidat Pembantu Dekan 1; Ibu Marlia Sastro, SH., M.Hum kandidat Pembantu Dekan 2; Ibu Herinawati, SH., M.Hum dan Ibu Eni Dameria, SH., M.Hum sebagai kandidat Pembantu Dekan 3. Pada periode awal, pembantu dekan terpilih adalah: Elidar Sari, SH., M.H. (PD 1); Jumadiah, SH., M.Hum (PD 2); Herinawati, SH., M.H (PD 3) dan 4) Muhammad Hatta, SH., L.LM (PD 4). Namun, dikarenakan adanya tuntutan kepada Pembantu Dekan 1 untuk mengundurkan diri sehubungan dengan alasan-alasan Tugas Belajar yang ada padanya dan berbagai kondisi lainnya maka posisi beliau digantikan oleh Zulfan, SH., M.Hum.
} 


\begin{tabular}{|c|l|l|c|c|}
\hline 4. & Pembantu Dekan 3 & Teuku Alfiady, S.Sos., M.Si & $\checkmark$ & - \\
\hline 5. & Pembantu Dekan 4 & Ti Aisyah, S.Sos., MSP & - & $\checkmark$ \\
\hline 6. & Kepala Bagian Tata Usaha & Lisa Abidin, SE & - & $\checkmark$ \\
\hline 7. & Kasubag Adm. Umum \& Keuangan & Eva Zahara, SH & - & $\checkmark$ \\
\hline 8. & $\begin{array}{l}\text { Kasubag Akademik \& } \\
\text { Kemahasiswaan }\end{array}$ & Elvi Linda, SE & - & $\checkmark$ \\
\hline 9. & $\begin{array}{l}\text { Ketua Jurusan Ilmu Adm. Negara } \\
\text { (IAN) }\end{array}$ & Maryam, S.Sos., M... & - & $\checkmark$ \\
\hline 10. & Sekretaris Jurusan IAN & Nur Hafni, S.Sos., M.PA & - & $\checkmark$ \\
\hline 11. & Kepala Lab. IAN & Mauludi, S.Sos., MSP & $\checkmark$ & - \\
\hline 12. & Ketua Prodi Sosiologi & Fajri, S.Sos., M.SSc & $\checkmark$ & - \\
\hline 13. & Sekretaris Prodi & Alwi, S.Sos., M.Si & $\checkmark$ & - \\
\hline 14. & Kepala Lab. Sosiologi & Ahmad Yani, S.Sos., M.Si & $\checkmark$ & - \\
\hline 15. & Ketua Prodi llmu Politik & $\begin{array}{l}\text { Dr. Muhammad Bin Abu Bakar, } \\
\text { B.HSc., MA }\end{array}$ & $\checkmark$ & - \\
\hline 16. & Sekretaris Prodi & Alfian, SHI., MA & $\checkmark$ & - \\
\hline 17. & Kepala Lab. llmu Politik & Taufik Abdullah, S.Ag., MA & $\checkmark$ & - \\
\hline 18. & Ketua Prodi Antropologi & Agung Utama Lubis, S.Sos., M.Si & $\checkmark$ & - \\
\hline 19. & Sekretaris Prodi & Amiruddin Ketaren, S.Sos., M.Sc & $\checkmark$ & - \\
\hline 20. & Kepala Lab. Antropologi & Mursyidin, S.Ag., MA & $\checkmark$ & - \\
\hline 21. & Ketua Prodi Ilmu Komunikasi & Deddy Satria, S.Sos., M.Si & $\checkmark$ & - \\
\hline 22. & Sekretaris Prodi & $\begin{array}{l}\text { Ade Muana Husniati, S.Sos., } \\
\text { M.Si }\end{array}$ & - & $\checkmark$ \\
\hline 23. & Kepala Lab. Ilmu Komunikasi & Anismar, S.Ag., M.Si & $\checkmark$ & - \\
\hline & & \multicolumn{1}{|c|}{ Jumlah } \\
\hline
\end{tabular}

Tabel 8. Pejabat di Lingkungan Fakultas Ekonomi

\begin{tabular}{|c|l|l|c|c|}
\hline \multirow{2}{*}{ No. Jabatan } & \multicolumn{1}{|c|}{ Nama } & \multicolumn{2}{c|}{ Jenis Kelamin } \\
\cline { 4 - 5 } & & & LK & PR \\
\hline 1. & Dekan & Wahyuddin, SE., M.Si., Ak & $\checkmark$ & - \\
\hline 2. & Pembantu Dekan 1 & Khairil Anwar, SE., M.Si & $\checkmark$ & - \\
\hline 3. & Pembantu Dekan 2 & Iswadi, SE., M.Si & $\checkmark$ & - \\
\hline 4. & Pembantu Dekan 3 & Anwar puteh, SE., ME & $\checkmark$ & - \\
\hline 5. & Pembantu Dekan 4 & Dr. Ichsan, ST., MPPM & $\checkmark$ & - \\
\hline 6. & Kepala Bagian Tata Usaha & Azhar, SE & $\checkmark$ & - \\
\hline 7. & Kasubag Adm. Umum \& Keuangan & - & - & - \\
\hline 8. & $\begin{array}{l}\text { Kasubag Akademik \& } \\
\text { Kemahasiswaan }\end{array}$ & - & - & - \\
\hline 9. & Ka. Lab. Bahasa & Henny Irawati, S.Ag & - & $\checkmark$ \\
\hline 10. & Ketua Jurusan Manajemen & Marzuki, SE., M.Si & $\checkmark$ & - \\
\hline 11. & Sekretaris Jurusan Manajemen & Husaini, SE., M.BA & $\checkmark$ & - \\
\hline 12. & Kepala Lab. Jurusan Manajemen & Nazir, SE & $\checkmark$ & - \\
\hline 13. & Sekretaris Lab. Jurusan Manajemen & Ghazali Syamni, SE., M.Si & $\checkmark$ & - \\
\hline 14. & $\begin{array}{l}\text { Ketua Jurusan Ilmu Ekonomi dan } \\
\text { Studi Pembangunan }\end{array}$ & Hijri Juliansyah, SP., M.Ec & $\checkmark$ & - \\
\hline 15. & $\begin{array}{l}\text { Sekretaris Jurusan Ilmu Ekonomi dan } \\
\text { Studi Pembangunan }\end{array}$ & Jariah Abu Bakar, SE & - & $\checkmark$ \\
\hline 16. & $\begin{array}{l}\text { Kepala Lab. Ilmu Ekonomi dan Studi } \\
\text { Pembangunan }\end{array}$ & Cut Putri Mellita Sari, SE., M.Si & - & $\checkmark$ \\
\hline 17. & $\begin{array}{l}\text { Sekretaris Lab. Ilmu Ekonomi dan } \\
\text { Studi Pembangunan }\end{array}$ & - & - & - \\
\hline
\end{tabular}




\begin{tabular}{|c|c|c|c|c|}
\hline 18. & Ketua Jurusan Akutansi & M. Haykal, SE., M.Si., Ak & $\checkmark$ & - \\
\hline 19. & Sekretaris Jurusan Akutansi & Amru Usman, SE., Ak., M.Sc & $\checkmark$ & - \\
\hline 20. & Kepala Lab. Akutansi & Naz'aina, SE., M.Si., Ak & & $\checkmark$ \\
\hline 21. & Sekretaris Lab. Akutansi & Razif, SE., M.Si & $\checkmark$ & \\
\hline 22. & Ketua Jurusan D III Kesekretariatan & Nurmala, SE., M.Si & - & $\checkmark$ \\
\hline 23. & $\begin{array}{l}\text { Sekretaris Jurusan D III } \\
\text { Kesekretariatan }\end{array}$ & Sullaida, SE., M.Si & - & $\checkmark$ \\
\hline 24. & Kepala Lab. D III Kesekretariatan & T. Ediyansyah, SE., M.Si & $\checkmark$ & - \\
\hline 25. & Sekretaris Lab. D III Kesekretariatan & Juni Ahyar, S.Pd., MP & $\checkmark$ & - \\
\hline \multirow{2}{*}{\multicolumn{3}{|c|}{$\begin{array}{rr} & \text { Jumlah } \\
\text { Jumlah Total }\end{array}$}} & 16 & 6 \\
\hline & & & \multicolumn{2}{|c|}{22} \\
\hline & & Prosentase & $73 \%$ & $27 \%$ \\
\hline
\end{tabular}

Tabel 9. Pejabat di Lingkungan Fakultas Teknik

\begin{tabular}{|c|c|c|c|c|}
\hline \multirow[t]{2}{*}{ No. } & \multirow[t]{2}{*}{ Jabatan } & \multirow[t]{2}{*}{ Nama } & \multicolumn{2}{|c|}{ Jenis Kelamin } \\
\hline & & & LK & PR \\
\hline 1. & Dekan & Ir. T. Hafli, MT & $\checkmark$ & - \\
\hline 2. & Pembantu Dekan 1 & Herman Fitrah, ST., MT & $\checkmark$ & - \\
\hline 3. & Pembantu Dekan 2 & Bustami, S.Si., MT & $\checkmark$ & $\checkmark$ \\
\hline 4. & Pembantu Dekan 3 & Ezwarsyah, ST., MT & $\sqrt{ }$ & - \\
\hline 5. & Pembantu Dekan 4 & Salwin, ST., MT & $\checkmark$ & $\checkmark$ \\
\hline 6. & Kepala Bagian Tata Usaha & Zakaria, SE & $\checkmark$ & $\checkmark$ \\
\hline 7. & Kasubag Adm. Umum \& Keuangan & Muliana, A.Md & - & $\checkmark$ \\
\hline 8. & $\begin{array}{l}\text { Kasubag Akademik \& } \\
\text { Kemahasiswaan }\end{array}$ & Elizar, S.Sos & - & $\checkmark$ \\
\hline 9. & Ketua Jurusan Teknik Sipil & Fasdarsyah, ST., MT & $\checkmark$ & - \\
\hline 10. & Sekretaris Jurusan Teknik Sipil & Fadhliani, ST., M.Eng & - & $\checkmark$ \\
\hline 11. & Kepala Lab. Struktur & Yulius Rief Alkhaly, ST., M.Eng & $\checkmark$ & - \\
\hline 12. & Kepala Lab. Transportasi & Hamzani, ST., MT & $\checkmark$ & \\
\hline 13. & Ketua Jurusan Teknik Arsitektur & - & - & - \\
\hline 14. & Sekretaris Jurusan Teknik Arsitektur & Bambang Karsono, ST., MT & $\checkmark$ & - \\
\hline 15. & $\begin{array}{l}\text { Kepala Lab. Jurusan Teknik } \\
\text { Arsitektur }\end{array}$ & Nova Purnamalisa, ST., M.Sc & - & $\sqrt{ }$ \\
\hline 16. & Ketua Jurusan Teknik Mesin & Zulfikar, ST., MT & $\checkmark$ & - \\
\hline 17. & Sekretaris Jurusan Teknik Mesin & Reza Putra, ST., M.Eng & $\checkmark$ & - \\
\hline 18. & Kepala Lab. Jurusan Teknik Mesin & Asnawi, ST., M.Sc & $\checkmark$ & - \\
\hline 19. & Ketua Jurusan Teknik Industri & Fatimah, ST., MT & - & $\checkmark$ \\
\hline 20. & Sekretaris Jurusan Teknik Industri & Syarifuddin, ST., MT & $\sqrt{ }$ & - \\
\hline 21. & Kepala Lab. Jurusan Teknik Industri & Ir. Suharto Tahir, MT & $\checkmark$ & - \\
\hline 22. & Ketua Jurusan Teknik Kimia & Nasrul ZA., ST., MT & $\checkmark$ & - \\
\hline 23. & Sekretaris Jurusan Teknik Kimia & Fikri Hasfita, ST., MT & $\checkmark$ & - \\
\hline 24. & Kepala Lab. Jurusan Teknik Kimia & Meriatna, ST., MT & - & $\checkmark$ \\
\hline 25. & Ketua Jurusan Teknik Elektro & M. Ikhwanus, ST., M.Eng & $\checkmark$ & - \\
\hline 26. & Sekretaris Jurusan Teknik Elektro & Misbahul Jannah, ST., MT & - & $\checkmark$ \\
\hline 27. & Kepala Lab. Jurusan Teknik Elektro & Muhammad, ST., M.Sc & $\checkmark$ & - \\
\hline 28. & Ketua Prodi Studi Informatika & Nurdin, S.Kom & $\checkmark$ & - \\
\hline 29. & Sekretaris Prodi Studi Informatika & Mukti Kamal, ST., M.IT & $\checkmark$ & - \\
\hline 30. & Kepala Lab. Prodi Studi Informatika & Fadlisyah, S.Si., MT & $\checkmark$ & - \\
\hline \multicolumn{3}{|c|}{ Jumlah } & 22 & $\mathbf{1 0}$ \\
\hline & & Jumlah Total & \multicolumn{2}{|c|}{32} \\
\hline & & Prosentase & $69 \%$ & $31 \%$ \\
\hline
\end{tabular}


Tabel 10. Pejabat di Lingkungan Fakultas Pertanian

\begin{tabular}{|c|c|c|c|c|}
\hline \multirow[t]{2}{*}{ No. } & \multirow[t]{2}{*}{ Jabatan } & \multirow[t]{2}{*}{ Nama } & \multicolumn{2}{|c|}{ Jenis Kelamin } \\
\hline & & & LK & PR \\
\hline 1. & Dekan & Ir. Jamidi, MP & $\checkmark$ & - \\
\hline 2. & Pembantu Dekan 1 & Setia Budi, SP., MP & $\checkmark$ & - \\
\hline 3. & Pembantu Dekan 2 & Lukman, SP., M.Si & $\checkmark$ & - \\
\hline 4. & Pembantu Dekan 3 & Saiful Adhar., S.Si., M.Si & $\checkmark$ & - \\
\hline 5. & Pembantu Dekan 4 & Faisal, SP., M.Si & $\checkmark$ & - \\
\hline 6. & Kepala Bagian Tata Usaha & Syarbaini, SE & $\checkmark$ & $\checkmark$ \\
\hline 7. & Kasubag Adm. Umum \& Keuangan & Ainul Mardiah, S.Sos & - & $\checkmark$ \\
\hline 8. & $\begin{array}{l}\text { Kasubag Akademik \& } \\
\text { Kemahasiswaan }\end{array}$ & 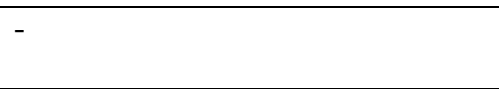 & - & - \\
\hline 9. & Ketua Prodi. Agribisnis & Rita Ariani, SP., M.Si & - & $\checkmark$ \\
\hline 10. & Sekretaris Prodi. Agribisnis & Fadli, SP., M.Si & $\checkmark$ & - \\
\hline 11. & Kepala Lab. Prodi. Agribisnis & Zuriani, SP., MP & - & $\checkmark$ \\
\hline 12. & Ketua Prodi. Budidaya Perairan & Erniati, S.Si., M.Si & - & $\checkmark$ \\
\hline 13. & Sekretaris Prodi. Budidaya Perairan & Erlangga, SP., M.Si & $\checkmark$ & - \\
\hline 14. & $\begin{array}{l}\text { Kepala Lab. Kualitas Air dan Nutrisi } \\
\text { Ikan }\end{array}$ & Munawwar Khalil, S.Pi., M.Si & $\checkmark$ & - \\
\hline 15. & $\begin{array}{l}\text { Kepala Lab. Hatheri dan Teknologi } \\
\text { Budidaya }\end{array}$ & Prama Hartami, S.Pi., M.S & $\checkmark$ & - \\
\hline 16. & Ketua Prodi. Agrokoteknologi & Muhammad Yunus, SP., M.P & $\checkmark$ & - \\
\hline 17. & Sekretaris Prodi. Agrokoteknologi & Nasruddin, SP & $\checkmark$ & - \\
\hline 18. & Kepala Lab. Agrokoteknologi & Nelly Fridayanti, SP., M.Si & - & $\checkmark$ \\
\hline 19. & Kepala Lab. Kultur Jaringan & Nilahayati, SP., M.Si & - & $\checkmark$ \\
\hline 20. & Kepala Kebun Percobaan & Zurahmi Wirda, SP., MP & - & $\bar{J}$ \\
\hline 21. & Kepala Lab. Ilmu Dasar Pertanian & Nazimah, SP., M.Si & - & $\checkmark$ \\
\hline \multicolumn{3}{|c|}{ Jumlah } & 12 & 9 \\
\hline & & Jumlah Total & \multicolumn{2}{|c|}{21} \\
\hline & & Prosentase & $57 \%$ & $43 \%$ \\
\hline
\end{tabular}

Tabel 11.Pejabat di Lingkungan Program Studi Pendidikan Dokter

\begin{tabular}{|c|l|l|c|c|}
\hline \multirow{2}{*}{ No. } & \multicolumn{2}{|c|}{ Jabatan } & & \multicolumn{2}{c|}{ Jenis Kelamin } \\
\cline { 4 - 5 } & & & LK & PR \\
\hline 1. & Ketua Prodi & dr. Razi Soangkupon S.MS & $\checkmark$ & - \\
\hline 2. & Sekretaris Prodi & dr. Cut Khairunnisa, M.Kes & - & $\checkmark$ \\
\hline 3. & Ketua Bidang Kemahasiswaan & Dr. Siti Maryam, M.Si & - & $\checkmark$ \\
\hline 4. & Kepala Bagian Tata Usaha & Dra. Ti Aminah & - & $\checkmark$ \\
\hline 5. & Ketua Medical Education Unit & dr. Muhammad Yusuf, Sp.S & $\checkmark$ & - \\
\hline 6. & Kepala Lab. Forensik & dr.. Cut Khairunnisa & - & $\checkmark$ \\
\hline 7. & Kepala Lab. Biokimia & dr. Noera Sovia Moeliza & - & $\checkmark$ \\
\hline 8. & Kepala Lab. Farnakologi & dr. Yuziani & - & $\checkmark$ \\
\hline 9. & Kepala Lab. Fisiologi & dr. Nizar Putri Mellaratna & - & $\checkmark$ \\
\hline 10. & Kepala Lab. Ilmu Gizi & dr. Noviana Zara & - & $\checkmark$ \\
\hline 11. & Kepala Lab. Mikrobiologi & dr. Juwita Sahputi & - & $\checkmark$ \\
\hline 12. & Kepala Lab. Kesehatan Masyarakat & dr. Furi Maulina & - & $\checkmark$ \\
\hline 13. & Kepala Lab. Histologi & dr. Agus Adhari & $\checkmark$ & - \\
\hline 14. & Kepala Lab. Anatomi & dr. Sulfi Halwi & - & $\checkmark$ \\
\hline 15. & Kepala Lab. Bagian Bedah & dr. M. Tambah, Sp.B., FinaCS & $\checkmark$ & - \\
\hline 16. & Kepala Lab. Patologi Anatomi & dr. Meutia Keumala Shah & - & $\checkmark$ \\
\hline 17. & Kepala Lab. Parasitologi & dr. Rizka Sofia & - & $\checkmark$ \\
\hline
\end{tabular}




\begin{tabular}{|r|l|l|c|c|}
\hline 18. & Kepala Lab. Patologi Klinik & dr. Husna, Sp. PK & - & $\checkmark$ \\
\hline 19. & Kepala Lab. Keterampilan Medik & dr. Irvan & - & $\checkmark$ \\
\hline \multicolumn{7}{|r|}{} & Jumlah Total & $\mathbf{4}$ & $\mathbf{1 5}$ \\
\hline \multicolumn{2}{|r|}{ Prosentase } & $\mathbf{2 1 \%}$ & $\mathbf{7 9 \%}$ \\
\hline
\end{tabular}

Akses untuk berada pada posisi setara antara laki-laki dengan perempuan harusnya dibuka selebar-lebarnya. Begitu juga halnya dengan penguatan partisipasi kepada perempuan-perempuan untuk dapat ikut serta mengajukan dirinya dalam berbagai kegiatan, program kerja bahkan sampai dengan kepemimpinan. Hal ini menjadi penting, dikarenakan - seringkali - ketika perempuan tidak berada pada posisi sentral sebagai pengambil kebijakan misalnya; atau sebagai pemegang kontrol maka keputusan-keputusan yang dapat memberikan perspektif kesetaraan menjadi minim. Walaupun juga sangat diakui bahwa bukan tidak mungkin, pemimpin laki-laki juga memiliki perpektif kesetaraan gender yang baik jika dibandingkan dengan perempuan. Hal ini dapat dilihat misalnya pada faktor manfaat yang diterima; apakah perempuan dan laki-laki mendapatkan manfaat yang setara akan hasil kebijakan yang ditetapkan oleh pimpinan? Baik dia pemimpin laki-laki maupun pemimpin perempuan.

Pada wawancara yang peneliti lakukan dengan kelompok kecil dosen di lingkungan Fakultas Hukum menjumpai informasi bahwa sebenarnya sebagai dosen kiranya tidak memberikan perbedaan perlakuan baik bagi mahasiswa maupun mahasiswi. Mereka memiliki hak yang sama untuk mengikuti perkuliahan di dalam kelas; memiliki hak yang sama untuk mendapatkan pelayanan akademik; sebagaimana mereka juga memiliki kewajiban yang sama untuk memenuhi semua beban perkuliahan. Seandainya terdapat sanksi-sanksi yang dibebankan kepada mahasiswa bersangkutan maka sifat akademis dari sanksi tersebutlah yang lebih ditonjolkan.

\section{Kesimpulan}

Sejauh ini, dalam konteks Universits Malikussaleh, posisi perempuan masih sering diperhadap-hadapkan dengan posisi laki-laki. Posisi perempuan selalu dikaitkan dengan lingkungan domestik yang berhubungan urusan dengan keluarga dan kerumahtanggaan. Sementara posisi laki-laki sering dikaitkan dengan lingkungan publik yang berhubungan dengan urusan-urusan di luar rumah. Dalam truktur sosial, posisi perempuan yang demikian sulit mengimbangi posisi laki-laki. Perempuan yang ingin berkiprah di lingkungan publik, masih sulit melepaskan diri dari tanggungjawabnya di lingkungan domestik. Perempuan dalam hal ini kurang berdaya untuk menghindar dari beban ganda tersebut karena tugasnya sebagai pengasuh anak sudah merupakan persepsi budaya secara umum. Kontrol budaya agaknya lebih ketat kepada perempuan daripada laki-laki.

Namun demikian, pihak universitas dan keluarga besar civitas academica Unimal terus memperbarui diri dan melakukan perubahan ke arah perbaikan yang substantif dan kredibel.

\section{Daftar Pustaka}

Cordelia Fine, (2010), Delusions of Gender: How Our Mind, Society and Neurosexism Create Differences", New-York: WW Norton and Companies, hlm. 214.

Aceh Declaration on Population and Gender, Banda Aceh: International Congress on Islam and Population Policy, (1990).

Nasaruddin Umar, Argumen Kesetaraan Gender -Perspektif Al Qur'an, Paramadina, Jakarta, 1999, halaman xxi - xxii.

Informasi ini didapat melalui Data Rekap mahasiswa Aktif Unimal, direkap oleh Ka.Bag Kemahasiswaan, per Oktober 2013. 
Jumlah staf honorer Unimal sebanyak 306 orang. Pada unit Satpam keseluruhannya laki-laki sebanyak 67 orang, dan pada unit kerja UPT PUSTAKA didominasi oleh honorer perempuan.

Wawancara dengan Ibu Tiainsyah, SH., Kasubag TU UPT. Perpustakaan, 12 Oktober 2013.

Wawancara dengan sekelompok mahasiswi penempuh matakuliah Pengantar Hukum Bisnis, Jurusan IESP, Fakultas Ekonomi, 4 April 2013.

Musliana (salah seorang mahasiswi di lingkungan kampus Bukit Indah), Wawancara 5 September 2013.

Wawancara dengan Desiana, Mahasiswi FH - Unimal, di Lhokseumawe, 9 September 2013.

Wawancara dengan T. Nazaruddin, di Lhokseumawe, tanggal 27 September 2013.

Wawancara dengan Ibu Manfarisyah (dosen perempuan senior di FH), Ibu Malahayati (Ketua Bagian Hukum Tata Negara pada FH), dan Ibu Rosmanita (Kabag TU Fak. Hukum), 19 Oktober 2013 dan Ibu Maryam (Ka. Prodi IAN - FISIP), 1 November 2013.

Wawancara dengan Fauzi, S.Sos., MA - Dekan FISIP Unimal, di Lhokseumawe, tanggal 2 November 2013. 